Printed in Great Britain

\title{
A CHECK-LIST OF BRITISH MARINE HALACARIDAE (ACARI), WITH NOTES ON TWO SPECIES OF THE SUB-FAMILY RHOMBOGNATHINAE
}

\author{
BY J. GREEN \\ Bedford College, University of London
}

(Text-figs. I-4)

Mites of the family Halacaridae are abundant on the sea shore, and in the sea down to considerable depths. Their identification is not an easy matter; there is no one account which can be used to identify all the British species, and the use of any one of the general accounts of European species, such as André (1946) or Viets (1936), by itself might easily lead to misidentification.

The purpose of the present list is to record the species which have so far been found around the British Isles, and to indicate sources of reliable descriptions of each species. A list of the British species of this family was given in a general list of British Acari by Turk (1953), and this has provided the starting point for the present list; no reference to occurrence in Britain before Turk's list is given, apart from one by Halbert (I920) which was left out by Turk. Twelve of the thirty-six species in the present list were not recorded by Turk. One species, Halacarus zosterae (Fab.), recorded by Turk has been omitted because the original description is quite inadequate to decide even which genus the creature should belong to. Eight species are known from British fresh water; these have not been included in the present list.

Only full species are given in this list, infra specific categories have been omitted. When the specific name is followed only by the author and date it indicates that the species was described from British material, and has not appeared in a general account of the group. The references in square brackets following the date indicate the source of a reliable description, while the succeeding references in rounded brackets give the authority for including the species as British.

The names in this list generally follow those given by Viets (1956) except that I have adopted Newell's (1947) classification of the Rhombognathinae, and the genus Copidognathus has not been divided into subgenera. 


\section{FAMILY HALACARIDAE Murray 1876 \\ SUbFAmily HaLACARINAE Viets 1927 \\ Gen. Halacarus Gosse, 1855}

Subgen. Halacarus Gosse, I855 s.str.

ctenopus Gosse, 1855 [Newell, 1947] (Turk, 1953)

actenos Trouessart, I889 [Newell, 1947] (Turk, 1953)

bisulcus Viets, I927 [Viets, 1936] (Spooner, 1959)

Subgen. Thalassarachna Packard, I87I (= Halacarellus Viets, 1927)

basteri (Johnston, I836) [Newell, I947] (Turk, I953)

southerni (Halbert, 1915)

areolatus (Halbert, 1915)

subterraneus (Schulz, 1933) [Newell, 1947] ${ }^{1}$

Gen. Copidognathus Trouessart, 1888

granulatus (Hodge, I863) [André, 1946, as C. glyptoderma Trs.]

(Turk, 1953)

rhodostigma (Gosse, I855) [André, 1946] (Turk, 1953)

loricifer André 1946 [André, 1946] (Turk, 1953)

fabricii (Lohmann, 1889) [André, 1946] (Turk, 1953)

tabellio (Trouessart, I894) [André, I946] (Turk, I953)

lamellosus (Lohmann, I893) [André, I946] (Turk, I953)

oculatus (Hodge, I863) [André, I946] (Turk, 1953)

gracilipes (Trouessart, 1889) [André, 1946] (Turk, 1953)

gibbus (Trouessart, 1889) [André, 1946] (Turk, 1953)

Gen. Agauopsis Viets, 1927

brevipalpus (Trouessart, 1889) [André, 1946] (Halbert, I920)

Subfamily PorohalaCarinae

Gen. Caspihalacarus Viets, 1928

hyrcanus Viets, I928 [Viets, I928a] (Green, I956)

SUBFAMILY RHOMBOGNATHINAE

Gen. Rhombognathus Trouessart, I888

notops (Gosse, I855) [Newell, 1956] (Turk, 1953)

magnirostris Trouessart, I889 [Newell \& André, I959] ${ }^{2}$

lionyx Trouessart, 1900 [Newell \& André, 1959 ${ }^{2}$

\footnotetext{
${ }^{1}$ This species has not previously been recorded from Britain. I have identified a single specimen from the Essex coast, near the mouth of the Thames.

${ }^{2}$ I have British specimens which agree with Newell and Andrés' recent redescription of these species.
} 
Gen. Isobactrus Newell, 1947

setosus (Lohmann, I889) [Newell, 1947] (Turk, 1953)

levis (Viets, 1927) [Newell, 1947] (Green, 1956a)

uniscutatus (Viets, 1939) [Viets, 1939] (Green, 1956a)

Gen. Rhombognathides Viets, 1927, emnd. Newell, I947

pascens (Lohmann, 1889) [Newell, 1947] (Turk, 1953)

spinipes (Viets, 1933) [Willmann, I952] (Green, I956a)

seahami (Hodge, 1860) [Newell, 1947] (Turk, 1953)

trionyx (Trouessart, I899) [André, I946] (Turk, 1953)

merrimani Newell, I947 [Newell, 1947] (Green, I956 b)

mucronatus (Viets, 1927) [Newell, 1947 $]^{1}$

Gen. Metarhombognathus Newell, 1947

armatus (Lohmann, 1893) [Newell, 1947] (Green, 1956 b)

nudus (Viets, 1928b) [Sokolov, 1952] (see below)

\section{SubFamily Simognathinae}

Gen. Simognathus

minutus (Hodge, 1863) [André, 1946 as S. sculptus] (Turk, I953)

SUBFAMILY LOHMANELLINAE

Gen. Lohmanella Trouessart, I90I

falcata (Hodge, I863) [André, I946] (Turk, 1953)

Gen. Scaptognathus Trouessart, I889

tridens Trouessart, 1889 [André, 1946] (Spooner, 1959)

trouessarti Halbert, I915

Two of the mites recorded in the above list are of interest for two distinct reasons. Their occurrences in Britain represent considerable extensions of their known ranges, and their systematic status needs clarification, particularly in relation to the subdivision of the subfamily Rhombognathinae.

\section{Metarhombognathus nudus (Viets)}

In $1928 b$ Viets described two species of the genus Rhombognathus from the Murmansk coast. Both species were found on the same alga, and one, $R$. nudus, was found only as the adult, while the other, $R$. contectus, was found

${ }^{1}$ Not previously recorded from Britain. I have a specimen from the Tees estuary, collected by Miss E. Clay. 


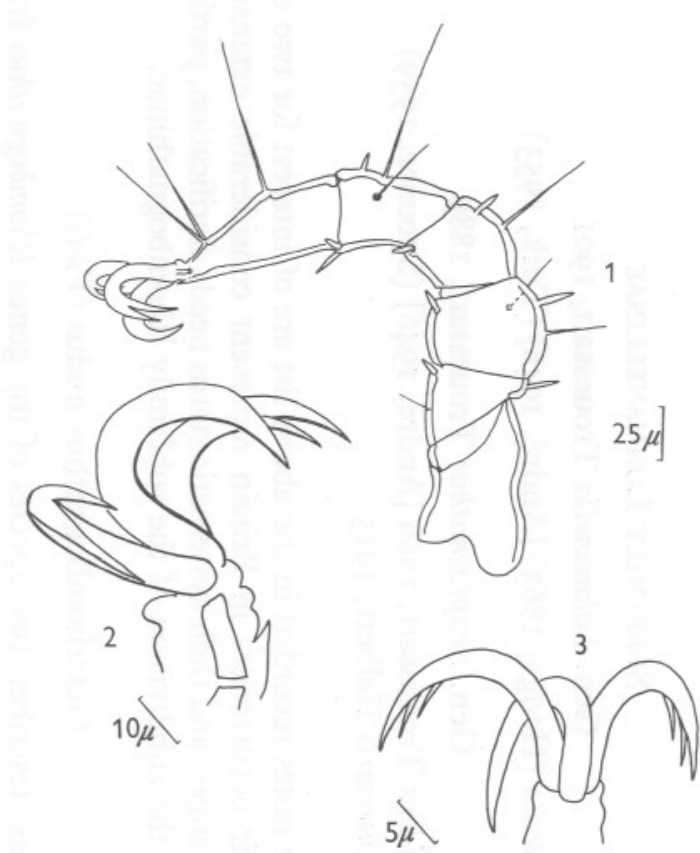

Figs. I-3. Metarhombognathus nudus. I, Leg IV of adult. 2, terminal claws of leg I of adult. 3, terminal claws of leg I of larva.

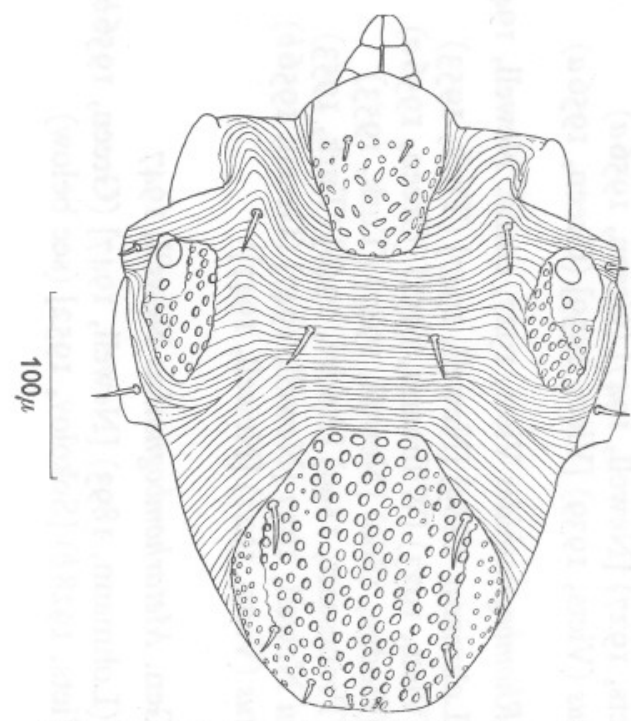

Fig. 4. Deutonymph of Metarhombognathus nudus, dorsal view of body. This specimen has a squarer posterior border to the anterior dorsal plate than most of the other specimens examined. 
only as the deutonymph. Newell (1947), on the basis of his experience with a similar pair of forms, suggested that the two were in fact only one species. As Newell puts it 'It is highly improbable that two extremely closely allied forms (as shown by the unique structure of the lateral claws) could occupy the same habitat, both forms being numerous, and yet one be known only as the adult and the other only as the deutonymph'.

The two species have not apparently been recorded in the literature since the original descriptions and a repetition of these by Sokolov (1952), who still regards them as separate species. In Viet's (I956) register of the Halacaridae the two forms are maintained as separate species.

In March 1959 specimens agreeing with the description of $R$. nudus were found in small splash pools at the bottom of the cliffs at Cullercoats, Northumberland. The mites were very numerous in these pools, and all stages from larvae to adults were found.

The principal difference between $R$. nudus and $R$. contectus is that the dorsal plates of the former are small while those of the latter are large. When a random sample of twenty-five specimens from Cullercoats was examined in detail after clearing in lactic acid three specimens were found to be larvae. These had very small dorsal plates; the body length, from the front of the anterior dorsal plate to the posterior tip of the body, ranged from 216 to $223 \mu$. Five of the series were protonymphs, with small dorsal plates, and body lengths ranging from 223 to $295 \mu$. Seven deutonymphs, ranging in length from 350 to $380 \mu$, were found; these all had large dorsal plates and would be identifiable as $R$. contectus. Ten adults, with small dorsal plates, and having body lengths of 320-500 $\mu$, completed the series.

This result of examining a random sample clearly indicates that $R$. contectus is the deutonymph of $R$. nudus. The latter name takes precedence owing to page priority. The finding that the protonymph has small dorsal plates like the adult is in agreement with Newell's description of the protonymph of Metarhombognathus armatus Lohmann, which has deutonymphs with large dorsal plates and adults with small dorsal plates. Newell has produced conclusive evidence that the deutonymphs of $M$. armatus with large dorsal plates are followed by adults with small dorsal plates by dissecting an adult from a quiescent deutonymph.

Further evidence that $R$. contectus is the deutonymph of $R$. nudus can be taken from the structure of the lateral claws. In the larvae, protonymphs and deutonymphs the lateral claws each carry two teeth on their inner borders (Fig. 3). This agrees with Viets figure of the claws of contectus. Nine of the adults had lateral claws with a single tooth on the inner border (Fig. 2), while one had two of its lateral claws with two teeth on their inner borders; it is noteworthy that this was the smallest of the adults. The loss of one of the teeth on the lateral claws appears to be normal when the adult stage is reached.

A further question is raised by the generic, or subgeneric, position of this 
species. The difficulty is that two different systems of classification have been proposed. Viets (1936, 1952, I956) regards the subfamily Rhombognathinae as consisting of a single genus Rhombognathus Trouessart, which he subdivides into three subgenera. Newell $(1947$, I953) regards the subfamily as comprising four genera. Using Viet's system the present species would be called Rhombognathus (Rhombognathopsis) nudus. I have, however, adopted Newell's system for reasons which will become apparent in the discussion of the next species.

\section{Rhombognathides merrimani Newell}

This species has been recorded in Britain from the following localities: Isle of Man (Green, I956a); Skokholm Island, Pembrokeshire (Green, I956a); Gwendraeth Estuary, Carmarthenshire, on Cladophora, and in the gut of Gobius minutus (Green, unpublished records). Previous to these records it was known only from North America.

Newell (1947) has given an admirably detailed description of this species, so that no further description is necessary here. The most important feature of this species, from a systematic point of view, is its occurrence in two varieties: merrimani having two claws on all its legs, and needleri having three claws on legs I and II, and two claws on legs III and IV. Apart from this difference in claw number the two varieties are identical. My British specimens include both varieties, and I am unable to find any other difference between them, so that I am convinced with Newell that they belong to the same species. Viets (1950, 1952, 1956) does not accept this; he regards the two forms as not only separate species, but belonging to different subgenera. This is necessary if Viet's classification of the Rhombognathinae is followed, since the subgenera are separated entirely on claw characters, as follows:

$\begin{array}{llcccc}\quad \text { Leg ... } & \ldots & \text { I } & \text { II } & \text { III } & \text { IV } \\ \text { Rhombognathus } & & 2 & 2 & 2 & 2 \\ \text { Rhombognathides } & & 3 & 3 & 2 & 2 \\ \text { Rhombognathopsis } & & 3 & 3 & 3 & 3\end{array}$

If the two forms of R. merrimanni are conspecific, as Newell and I believe, then Viet's classification must fall, and a substitute be found. I have adopted Newell's system because it is based upon an analysis of a considerable number of characters and it groups together species which are obviously closely allied although they may differ in claw number. The alternative to Newell's system would be to keep the single genus Rhombognathus and not divide it further, this would be a negative attitude, resulting in a genus of some thirty species with no expression of affinities within the group.

The specimens of Metarhombognathus nudus were collected while running a marine biology course for students at the Dove Marine Laboratory, Cullercoats. It is a pleasure to thank Dr H. O. Bull and his staff for the facilities which they made available to us. 


\section{SUMMARY}

A check list of British marine mites of the family Halacaridae is given.

Metarhombognathus nudus (Viets), hitherto known only from the Barents Sea, is recorded from Cullercoats, Northumberland. Evidence is presented which indicates that the form described as Rhombognathus contectus Viets is the deutonymph of Metarhombognathus nudus.

The known distribution of Rhombognathides merrimani Newell in Britain is summarized, and its systematic status in relation to the classification of the Rhombognathinae is discussed. It is recommended that Newell's classification of this subfamily be adopted.

\section{REFERENCES}

ANDRÉ, M., 1946. Halacariens marins. Faune Fr., No. 46, I52 pp.

GrEen, J., I956a. Additions to the British Halacaridae (Acari). Ent. mon. Mag., Vol. 92, p. 334.

- 1956 b. Halacarid and porohalacarid mites from Skokholm Island and the Isle of Man. Ann. Mag. nat. Hist., Ser. I2, Vol. 9, pp. 545-8.

HAlBert, J. N., I9I5. Clare Island Survey. Acarinida: terrestrial and marine Acarina. Proc. R. Irish Acad., Vol. 3I, Part 39 ii, pp. 45-136.

1920. The Acarina of the seashore. Proc. R. Irish Acad., B, Vol. 35, pp. 106-52.

NewELL, I. M., I947. A systematic and ecological study of the Halacaridae of Eastern North America. Bull. Bingham. oceanogr. Coll., Vol. Io, Pt. 3, 232 pp. I953. The natural classification of the Rhombognathinae (Acari, Halacaridae). System. Zool., Vol. 2, pp. II9-35.

- 1956. Pachygnathus notops Gosse 1885-100 years later. Ann. Mag. nat. Hist., Ser. I2, Vol. 9, pp. 465-75.

Newell, I. M. \& ANDRÉ, M., I959. Révision des espèces de Rhombognathus (Halacariens marins), décrites parÉdouard L. Trouessart. Acarologia, Vol. I, pp. I24-46.

Sokolov, I. I., I952. Water Mites, Part II. Halacarae. Fauna S.S.S.R., Vol. 5, 200 pp. Moscow.

SPOONER, G. M., I959. New members of the British marine bottom fauna. Nature, Lond., Vol. I83, pp. 1695-6.

Turk, F. A., 1953. A synonymic catalogue of British Acari: Part I. Ann. Mag. nat. Hist., Ser. 12, Vol. 6, pp. I-26.

VIETS, K., I928a. Wassermilben aus dem Schwarzen Meer, dem Kaspischen Meer und dem Aral-See. Abh. naturw. Ver. Bremen, Bd. 27, pp. 47-80.

- I928b. Halacaridae von der Murman-Küste, aus dem Weissen Meere und von Nowaja-Semlja. Explor. Mers russes, Fasc. 6, pp. 8I-8.

- I936. Wassermilben oder Hydracarina (Hydrachnellae und Halacaridae). In Dahl, Tierwelt Dtsch., Bd. 31, pp. I-574.

- 1939. Meeresmilben aus der Adria. Arch. Naturgesch., N.F., Bd. 8, pp. 518-50. 1950. Die Meeresmilben (Halacaridae, Acari) der Fauna Antarctica. Further zool. Res. Swed. Antarct. Exped., Vol. 4, pp. I-44.

- 1952. Diskussion einiger Halacariden-Genera (Acari). Veröff. Mus. Nat. Bremen, A, Bd. 2, pp. 9I-IO4.

- 1956. Die Milben des Süsswassers und des Meeres. Hydrachnellae et Halacaridae. Parts 2 and 3, 870 pp. Jena.

WILlmanN, C., I952. Die Milbenfauna der Nordseeinsel Wangerooge. Veröff. Inst. Meeresforsch. Bremerhaven, Bd. I, pp. 139-86. 